\title{
Nitric oxide in gingival crevicular fluid and nitric oxide synthase expression in the gingiva of patients with sickle cell disease
}

\author{
Orak hücre anemili hastaların dişetlerindeki nitrik oksit sentetaz \\ ekspresyonu ve dişeti oluğu sıvılarındaki nitrik oksit \\ düzeyinin değerlendirilmesi
}

\author{
Esra Güzeldemir ${ }^{1}$, Hilal Uslu Toygar ${ }^{2}$, Nebil Bal ${ }^{3}$, Ruksan Anarat ${ }^{4}$, Can Boğa ${ }^{5}$ \\ ${ }^{1}$ Department of Periodontology, Faculty of Dentistry, Kocaeli University, Kocaeli, Turkey \\ 2Department of Periodontology, Faculty of Dentistry, Baskent University, Ankara, Turkey \\ ${ }^{3}$ Department of Pathology, Faculty of Medicine, Baskent University, Ankara, Turkey \\ ${ }^{4}$ Department of Biochemistry, Faculty of Medicine, Baskent University, Ankara, Turkey \\ ${ }^{5}$ Department of Hematology, Faculty of Medicine, Baskent University, Ankara, Turkey
}

\begin{abstract}
Objective: This study aimed to biochemically measure the production of nitric oxide in gingival crevicular fluid and immunohistochemically measure the expression of inducible nitric oxide synthase in the gingiva of patients with sickle cell disease. Additionally, we aimed to obtain insight into the immunopathology of sickle cell disease by comparing inducible nitric oxide synthase levels in patients with sickle cell disease and controls using gingiva and gingival crevicular fluid.

Materials and Methods: The study included 20 sickle cell disease patients and 20 healthy controls. Immunohistochemical analysis was used to measure inducible nitric oxide synthase expression in gingiva and nitric oxide levels in gingival crevicular fluid were spectrophotometrically measured.

Results: Nitric oxide levels in the patients and controls did not differ significantly $(21.2 \pm 4.5$ and $23.1 \pm 2.3 \mu \mathrm{M} \mathrm{L}^{-1}$, respectively, $\mathrm{p}>0.05$ ). There weren't any statistically significant differences in infiltrated inflammatory cells, density of inflammatory cells that stained with inducible nitric oxide synthase, or nitric oxide expression in gingiva between the patient and control groups $(p>0.05)$.

Conclusion: To the best of our knowledge this is the first study to examine the expression of inducible nitric oxide synthase in the gingiva and gingival crevicular fluid in patients with sickle cell disease. Using the gingiva and gingival crevicular fluid we were unable to observe sickle cell disease-associated inducible nitric oxide synthase expression and a difference in nitric oxide levels.
\end{abstract}

(Turk J Hematol 2011; 28: 115-24)

Key words: Sickle cell disease, nitric oxide, nitric oxide synthase, gingival crevicular fluid, gingiva

Received: June 22, 2009

Accepted: June 16, 2010 


\section{Özet}

Amaç: Çalışmamızda, orak hücre anemili hastaların, dişeti dokusunda immünohistokimyasal yöntemle nitrik oksit sentetaz ekspresyonunun ve dişeti oluğu sıvısında biyokimyasal yöntemle nitrik oksit düzeyinin değerlendirilmesi amaçlanmıştır.

Yöntemler ve Gereçler: Çalışmaya, 20 orak hücre anemili hasta ve her yönden sağllklı 20 kontrol kişi alınmıştır. Dişeti dokusundaki nitrik oksit sentetaz ekspresyonu immünohistokimyasal yöntemlerle, dişeti oluğu sıvısındaki nitrik oksit düzeyi ise spektrofotometrik yöntemlerle ölçülmüştür.

Bulgular: Hasta ve kontrol gruplarında, dişeti oluğu sıvısındaki nitrik oksit düzeyleri arasında istatistiksel olarak anlamlı bir fark bulunmamıştır $\left(21.2 \pm 4.5\right.$ ve $\left.23.1 \pm 2.3 \mu \mathrm{M} \mathrm{L}^{-1}, \mathrm{p}>0.05\right)$. Gruplar arasında, inflamatuvar hücre yoğunluğu, nitrik oksit sentetazla boyanan inflamatuvar hücrelerin yoğunluğu ve nitrik oksitle boyanan bu hücrelerde görülen ekspresyonun yoğunluğu açısından anlamlı bir fark görülmemiştir ( $p>0.05)$.

Sonuç: Araştırmalarımıza göre, bu çalışma, orak hücre anemili hastaların dişeti dokusunda ve dişeti oluğu sıvısında nitrik oksit düzeyini ve nitrik oksit sentetaz ekspresyonunu değerlendiren ilk çalışmadır. Çalışmamızda dişeti dokularında ve dişeti oluğu sıvısında, orak hücre anemisi ile ilişkili olarak, farklı nitrik oksit düzeyleri ve ekspresyonu görülmemiştir. (Turk J Hematol 2011; 28: 115-24)

Anahtar kelimeler: Orak hücre anemisi, nitrik oksit, nitrik oksit sentetaz, dişeti oluğu sıvısı, dişeti

\section{Introduction}

Sickle cell disease (SCD) is the result of hemoglobin $\mathrm{S}$ homozygosity, which causes rigid sickle erythrocytes. Interactions between abnormal rigid erythrocytes and the vascular wall result in endothelial activation, which may lead to endothelial damage and tissue ischaemia in SCD. Chronic inflammation during both the steady state and vasoocclusive crisis occurs via the action of cytokines and other inflammatory factors [1-4]. The clinical manifestations of the disease, such as painful crises, anemia, bone necrosis, and leg ulceration, arise due to chronic hemolysis, vaso-occlusion, ischemia, and tissue damage.

Nitric oxide (NO) is a short-lived free radical that influences physiological processes in virtually every tissue and is derived from L-arginine via the action of constitutive NO synthase (NOS) or inducible NO synthase (iNOS), whose activity is induced in several cell types, including human gingival fibroblasts. iNOS expression results in increased production of NO and is activated during cellular distress, systemic inflammation, hypoxia, and oxidative stress. $\mathrm{NO}$ is a molecule involved in vascular regulation, homeostasis, bone formation and resorption, neurotransmission, and immune function. It plays a role in host defense response to infection in oral tissues [5]. NO mediates physiologic processes in the immune, inflammatory, nervous, cardiovascular, and pulmonary systems.
In infection and the resultant inflammatory responses, NO plays a dual role: it is a central mediator of host response, but also is an important agent in the pathogenesis of host damage [6]. Decreased levels of L-arginine, and consumption of NO by cellfree plasma hemoglobin and by reactive oxygen species (ROS) appear to impair NO bioavailability, resulting in oxidative damage. Because SCD is associated with oxidative stress, increased expression of endothelial cell adhesion molecules, and blood cell adhesion, which are characteristic features of an inflammatory response, several researchers have studied the role of iNOS in SCD [7].

The intermittent vascular occlusion that occurs in SCD leads to ischemia-reperfusion injury and activation of inflammatory processes, including enhanced production of ROS and increased expression of iNOS. Increased iNOS expression and a consequent increase in tissue nitrite and nitrate production have been observed in the kidneys and liver of SCD patients [8], mice [2,3,8,9], and pigs [4]. Additionally, it was shown that iNOS inhibition significantly limits tissue ischemia-reperfusion injury in the liver and kidneys [10,11]; however, inhibition of iNOS attenuated ischemia-reperfusion injury in the rat heart [12] and did not affect ischemia-reperfusion injury in the rat lung [13]. Increased levels of iNOS expression were shown in the kidneys of transgenic mice [9], but Nath et al. [14] reported the lack of upregulation of iNOS in the intrarenal vasculature and increased expression of iNOS in the 
glomeruli and distal tubules of sickle mice. The role of iNOS and its expression seems to vary by organ.

In addition, $\mathrm{NO}$ metabolites $\left(\mathrm{NO}_{\mathrm{x}}\right.$; nitrate $\left[\mathrm{NO}_{3}{ }^{-}\right]$ and nitrite $\left[\mathrm{NO}_{2}^{-}\right]$) in SCD were evaluated in blood samples in vivo [15-17] and in vitro [18]. It was reported that NOS activity plays a role in stimulating production of $\mathrm{NO}_{\mathrm{x}}$. iNOS was observed in dental tissues, and increased iNOS production was reported in gingival crevicular fluid (GCF) [19] and gingival tissues [20-23] in different periodontal diseases, but iNOS activity was not observed in the gingival tissues in sterile animals [24]. Periodontal diseases are inflammatory disorders that cause tissue damage and loss via the complex interactions between pathogenic bacteria and host immune response. Oxidative stress also plays a role in the pathogenesis of periodontal diseases; this causes an imbalance between the antioxidant and pro-oxidant systems. $\mathrm{ROS}$ and reactive nitrogen species (NO, $\mathrm{NO}_{2}^{-}$, and $\mathrm{ONOO}^{-}$) are also contributors to this process.

NO synthesis and iNOS activity increase in inflamed periodontal tissues [20,25-28] as a result of macrophage infiltration in periodontal tissues [29]. The literature includes only a few studies that evaluated iNOS activity in inflamed periodontal tissues. iNOS activity was reported to increase in ligatureinduced periodontitis [27], experimental periodontitis [30], and chronic periodontitis [20,26,31]. Higher levels of iNOS expression were observed in chronic periodontitis tissues than in clinically healthy gingival tissues [20,23,26,27,31] and a previous study of ours showed that iNOS increased in the gingival tissue of aggressive periodontitis patients (unpublished data). In various animal models iNOS was susceptible to infections by a variety of pathogens [32-35]. It was shown that NO plays an important role in the pathogenesis of chronic inflammation [36]. iNOS is expressed almost exclusively during inflammatory conditions, which has led to the hypothesis that iNOS has detrimental effects on inflamed tissues and promotes the inflammatory response [37].

While data regarding dental and periodontal conditions is SCD patients are limited, there are no data regarding NO levels and the presence/expression of iNOS in the gingival tissues and GCF of SCD patients. GCF is inflammatory exudates that can be easily collected from gingival crevices of teeth by means of paper strips. Host cell-derived inflammatory tissue response and bacterial products in GCF were assessed in studies related to markers of pathogenesis and the diagnosis of periodontal disease [38].

To the best of our knowledge the present study is the first to examine NO levels and the presence/ expression of iNOS in the gingiva and GCF of patients with SCD. Findings regarding NO levels and the expression of iNOS in different tissues and organs in SCD patients are inconsistent. The role of iNOS and its expression appears to vary in each organ in patients with SCD. It is well documented that iNOS is expressed in inflamed gingiva in different conditions and diseases. Ongoing chronic inflammatory reactions in SCD patients result in increased iNOS expression; therefore, the aim of the present study was to evaluate NO levels and the presence/expression of iNOS in the gingival tissues and GCF in SCD patients, as well as to obtain insight into the immunopathology of SCD in gingiva and and GCF, in terms of iNOS metabolism.

\section{Methods}

\section{Study population}

This study was conducted at Başkent University, Adana Medical and Research Center between January and August 2007. The Başkent University Ethics Committee (D-KA07/01) approved the study protocol. Samples were evaluated at Başkent University, Adana Medical and Research Center, Departments of Pathology and Biochemistry. All the participants provided informed consent. Evaluation of each participant consisted of personal, medical, and dental history, and panoramic radiographs and dental examinations. The inclusion criterion was age $\geq 18$ years.

The study included 20 homozygous SCD patients in the steady stae that had not received blood transfusions in the preceding 3 months. The patients' genotypes were confirmed by electrophoresis. The SCD patients were seen regularly at the Başkent University Hematology Clinic. As part of a standard medical examination they were sent to the Department of Periodontology for dental and periodontal examination and consultation.

The control group included 20 age- and sexmatched volunteers without a history of SCD. Exclusion criteria were as follows: history of hepatitis, HIV infection, or diabetes, requirement for antibiotic 
prophylaxis, pregnancy or lactation, and long-term use of anti-inflammatory drugs. All the participants were free of systemic, and dental and periodontal diseases. Both groups consisted of non-smokers.

\section{GCF sampling and analysis}

Assessment of total $\mathrm{NO}$ metabolites $\left(\mathrm{NO}_{\mathrm{x}}\right.$ : nitrate $\left[\mathrm{NO}_{3}{ }^{-}\right]$and nitrite $\left.\left[\mathrm{NO}_{2}^{-}\right]\right)$is commonly used as a measure of NO production in biologic fluids. GCF samples were obtained using standard paper strips (Periopaper, Ora Flow Inc., NY, USA ) following isolation of the tooth with cotton rolls and removal of any supragingival deposits on tooth surfaces. The collection region was gently air-dried for $2 \mathrm{~s}$ to reduce any contamination by plaque and saliva. The strip was left at the entrance of the gingival sulcus for $30 \mathrm{~s}$. GCF volume was calculated using a Periotron 8000 (Periotron 8000, Pro Flow Inc., Amityville, NY, USA ) device, which was pre-calibrated with a dry, sterile strip. Samples with evidence of bleeding were not included. After volume determination, GCF samples were placed in sterile Eppendorf tubes that were wrapped securely and stored at $-20^{\circ} \mathrm{C}$ until analyzed. The same periodontist (E.G.) performed all clinical GCF sampling.

\section{Quantification of nitrate/nitrite content in GCF}

There are numerous direct and indirect analytical methods for the quantification of NO in aqueous solutions, but only a few are applicable to biological fluids, as NO is highly reactive, has a short half-life in vivo, and is produced in small quantities in cells. The method used in the present study is based on the quantification of the stable end products of nitric oxide-nitrate and nitrite. Nitrate determination requires chemical and enzymatic reduction to nitrite. This method is easy, quick, inexpensive, and more sensitive (to micromolar range) than other methods [39].

To each GCF sample in an Eppendorf tube was added $130 \mu \mathrm{L}$ of distilled water. The samples were mixed to extract nitrate into the water. To measure nitrate levels $100 \mu \mathrm{L}$ of the extract was obtained from the mixture and evaluated using the nitrite/ nitrate colorimetric test (Nitrite/Nitrate Colorimetric Test, Roche, Germany). The colorimetric reaction was allowed to proceed for $10 \mathrm{~min}$ at room temperature, and then the optical density (absorbance, OD) at $540 \mathrm{~nm}$ was measured at room temperature using a spectrophotometer (Elisa, Merck, Germany). The measured OD values were converted to concentrations using a standard curve established by the serial dilution of nitrate. Analyses were performed on coded samples by 1 of the authors (R.A.) that was blinded to the participants' diagnoses.

\section{Gingival biopsy collection and analysis}

The patients underwent gingival biopsy under local anesthesia. Local anesthetic agent without adrenalin was administered following application of a topical anesthetic agent. An inverse bevel incision was used to obtain tissue from the underside of the papilla. After washing with sterile $0.15 \mathrm{M}$ saline solution, gingival biopsy specimens were fixed in 10\% formalin solution and sent to the Pathology Department. Gingival tissue biopsy samples were collected by the same periodontist (E.G.) and analyses were performed on coded samples by another author (N.B.) that was blinded to the participants' diagnoses.

After routine paraffin tissue procedures, tissues were embedded in paraffin blocks. Then, $4-5-\mu \mathrm{m}$ thick sections were obtained from the paraffin blocks, and serial sections were immunostained with an AEC (3-amino-9-ethylcarbazole) substrate system and biotin-streptavidin complex system (3-amino-9-ethyl-carbazole [AEC]+ready-to-use substrate-chromogen K3469, DAKO, Denmark). AEC is a widely used chromogen for immunohistochemical staining. Deparaffinization and rehydration of the sections were followed by blocking endogenous peroxidase activity via incubation of the sections in $3 \% \mathrm{H} 2 \mathrm{O} 2$ for $30 \mathrm{~min}$ at room temperature. After rinsing with distilled water the sections were treated in a microwave oven with $10 \mathrm{mM}$ citrate buffer $(\mathrm{pH}$ 6.0 ) at $500^{\circ} \mathrm{C}$ for $5 \mathrm{~min}, 600^{\circ} \mathrm{C}$ for $4 \mathrm{~min}$, and then $700^{\circ} \mathrm{C}$ for $3 \mathrm{~min}$ for antigen retrieval. The slides were left to cool at room temperature for $50 \mathrm{~min}$. After rinsing with phosphate-buffered saline (PBS) for 2-3 min the slides were kept in $3 \% \mathrm{H}_{2} \mathrm{O}_{2}$ for 20 min, and then rinsed with PBS for 5 min. Non-specific binding was reduced with protein blocking serum for 20 min. Sections were incubated with iNOS primary polyclonal antibody (ready-to-use rabbit polyclonal antibody RB-1605-R7, Lab-Vision, CA, USA) at room temperature overnight. After rinsing with PBS for 2-3 min the sections were incubated with biotinylated goat antipolyvalent (Thermo Scientific Lab Vision 
TP-060-HL, Fremont, CA, USA) for 20 min. The sections were then washed with PBS for 2-3 min, treated with streptavidin peroxidase (ready-to-use TS-060-HR, Thermo Scientific, Lab Vision, Fremont, CA, USA) for $20 \mathrm{~min}$, and washed with PBS for 2-3 min. To visualize antibody binding a biotin-streptavidin complex system was used, followed by washing with distilled water, and then the sections were counterstained with Mayer's hematoxylin.

Immunohistochemical slides were used for morphological identification of neutrophils, lymphocytes, and macrophages. Immunohistochemical slides were examined for positive staining using light microscopy. Inflammation in each case was rated according to a modified scoring system [40-41] shown in Table 1, as follows: no inflammation (0), minimal inflammation (1), mild inflammation (2), moderate inflammation (3), and diffuse inflammation (4). In all, 5 high-power fields (40× magnification) per patient and control sample were examined, and the percentage of inflammatory cells expressing iNOS was scored as 0 (0\%-1\%), 1 (2\%-20\%), 2 (21\%-50\%), and 3 $(\geq 51 \%)$. In addition, the intensity of staining was evaluated, as follows: 0 (absent), 1 (weak), 2 (strong). Because AEC was used as a color reagent, orangebrown staining in cytoplasm was considered as positive for iNOS activity in inflammatory cells.

\section{Statistical analysis}

Statistical analyses were performed using SPSS v.11.0 for Windows (Statistical Product and Service Solutions, SSPS Inc, Chicago, IL, USA). Normality was analyzed using the Shapiro-Wilk test. The Mann-Whitney $U$ test and independent samples $t$ test was used to compare differences between the patients and controls. Spearman's rank correlation coefficient was used to analyze the relationships between all parameters. $P$ values $<0.05$ were considered statistically significant.

\section{Results}

In all, 20 homozygous SCD patients in the steady state and 20 healthy age- and sex-matched controls without a history of SCD were evaluated.

\section{Determination of NO production}

Total $\mathrm{NO}$ end metabolites $\left(\mathrm{NO}_{\mathrm{x}}\right.$ : nitrate $\left[\mathrm{NO}_{3}{ }^{-}\right]$ and nitrite $\left.\left[\mathrm{NO}_{2}^{-}\right]\right)$were quantified in the GCF of 20 patients with SCD and 20 controls. $\mathrm{NO}_{\mathrm{x}}$ in GCF ranged from 4.45 to $29.37 \mu \mathrm{M} \mathrm{L}^{-1}$ in SCD patients and 17.81 to $27.88 \mu \mathrm{M} \mathrm{L}^{-1}$ in the controls. Mean NO concentration in GCF was higher in the controls $\left(23.1 \pm 2.3 \mu \mathrm{M} \mathrm{L}^{-1}\right)$ than in the SCD patients $(21.2 \pm 4.5$ $\left.\mu \mathrm{M} \mathrm{L}^{-1}\right)$; the difference was not statistically significant $(\mathrm{p}=0.098)$ (Table 2). Sampling volume was $33.9 \pm 21.2 \mu \mathrm{L}$ in the SCD patients and $25.8 \pm 11.1 \mu \mathrm{L}$ in the controls; a significant difference was not observed $(p=0.139)$.

\section{Assessment of iNOS expression}

In total, 37 gingival biopsy tissue specimens were evaluated for iNOS levels and expression; 17 from SCD patients and 20 from controls. Inflammation intensity, density of iNOS(+) inflammatory cells, and iNOS expression were measured (Table 1). Inflammation intensity indicates the intensity of inflammatory cell infiltration, iNOS expression indicates the level of iNOS expression in iNOS-expressed inflammatory cells, and density of iNOS $(+)$ inflammatory cells is the percentage of cells expressing iNOS [31].

All tissues from both groups had few, but evident inflammatory cells present in connective tissue. There weren't any differences in inflammation intensity, percentage of cells expressing iNOS, or iNOS expression intensity between the patient and

Table 1. Evaluation of gingival biopsy specimen sections

\begin{tabular}{lccccc}
\hline $\begin{array}{l}\text { Inflammation } \\
\text { Intensity }\end{array}$ & $\begin{array}{c}\text { Density of iNOS (+) } \\
\text { Inflammatory Cells }\end{array}$ & \multicolumn{2}{c}{$\begin{array}{c}\text { iNOS } \\
\text { Expression }\end{array}$} \\
\hline Absent & 0 & Absent & 0 & Absent & 0 \\
Minimal & 1 & $<20 \%$ & 1 & Weak & 1 \\
Slight & 2 & $20 \%-50 \%$ & 2 & Strong & 2 \\
Moderate & 3 & $\geq 51 \%$ & 3 & & \\
Diffuse & 4 & & & & \\
\hline
\end{tabular}

Table 2. Volume and concentration of total NO products (nitrite/nitrate) in the SCD patients and controls

\begin{tabular}{lccc}
\hline & $\begin{array}{c}\text { SCD Patients } \\
(\mathbf{n}=20) \\
\text { mean } \pm \text { SD } \\
\text { median (range) }\end{array}$ & $\begin{array}{c}\text { Controls } \\
(\mathbf{n}=20)\end{array}$ & $\begin{array}{c}\text { p } \\
\text { mean } \pm \text { SD } \\
\text { median (range) }\end{array}$ \\
\hline Concentration $\left(\mu \mathrm{M} \mathrm{L}^{-1}\right)$ & $21.2 \pm 4.5$ & $23.1 \pm 2.3$ & 0.098 \\
& 21.69 & 22.85 & \\
& $(14.45-29.37)$ & $(17.81-27.88)$ & \\
Sample volume $\left(\mu \mathrm{L}^{-1}\right)$ & $33.9 \pm 21.2$ & $25.8 \pm 11.1$ & 0.139 \\
& $32.50(8-100)$ & $22.50(11-55)$ & \\
\hline
\end{tabular}


control samples (Table 3); however, all immunohistochemical parameters were strongly correlated in the SCD group (inflammation intensity and density of $\mathrm{iNOS}(+)$ inflammatory cells: $\mathrm{r}=0.604, \mathrm{p}<0.05$; inflammation intensity and iNOS expression: $\mathrm{r}=0.609, \mathrm{p}<0.01$; iNOS expression and density of iNOS $(+)$ inflammatory cells: $r=0.979, p<0.001)$ and in the control group (inflammation intensity and density of iNOS $(+)$ inflammatory cells: $r=0.669$, $\mathrm{p}<0.01$; inflammation intensity and iNOS expression: $\mathrm{r}=0.741, \mathrm{p}<0.001$; iNOS expression and density of iNOS $(+)$ inflammatory cells: $r=0.943$, $\mathrm{p}<0.001$ ) (Table 4).

In the present study immunohistochemical staining of the samples obtained from SCD patients (Figure a) and controls (Figure b) confirmed the lack of inflammatory iNOS-expressing cells in connective tissue (40× magnification). Stained cells were scattered in the connective tissues. Some of the basal layer of epithelium cells exhibited sparse positive staining.

\section{Discussion}

To the best of our knowledge the present study is the first to examine the NO level in the gingiva and the presence/expression of iNOS in GCF in SCD patients. The present findings indicate that NO levels and iNOS expression in SCD patients did not significantly differ from those in the controls.

iNOS expression was observed in chronic inflammatory diseases of the airway, blood vessels, bowel,

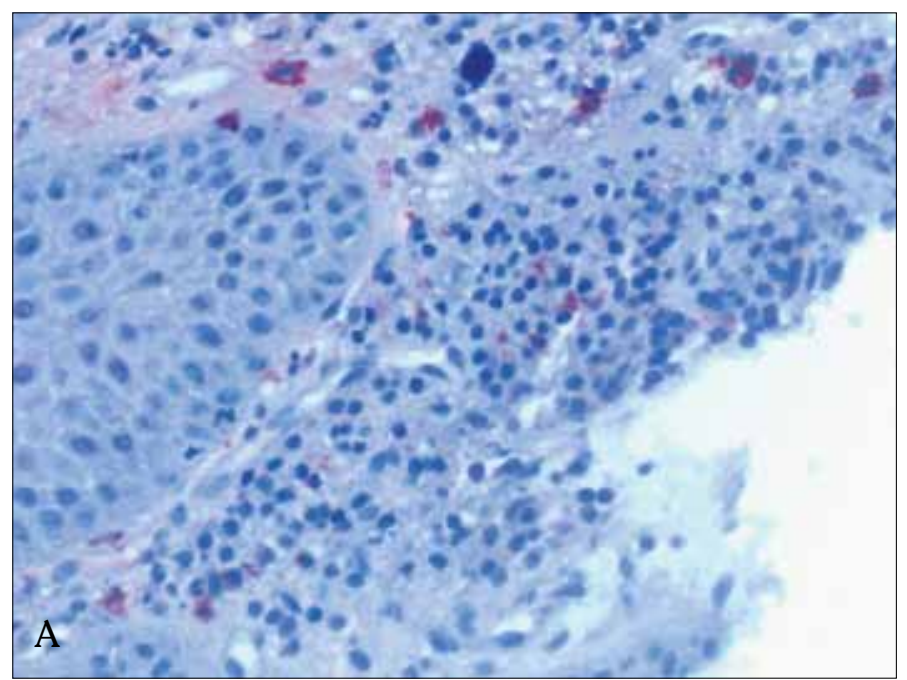

kidneys, heart, skin, and gingiva. It was suggested that the serum NO level is elevated in megaloblastic anemia [42] and that the plasma NO level in betathalassemia minor patients is low at the time of diagnosis [43]. In addition, excessive salivary NO plays a potential role in modifying oral mucosal diseases, as a physiopathological regulator [44]. Many recent studies have reported increased NO production in

Table 3. Median inflammation intensity, density of iNOS(+) inflammatory cells, and iNOS expression in the SCD patients and controls

\begin{tabular}{lccc}
\hline & $\begin{array}{c}\text { SCD Patients } \\
(\mathbf{n}=17) \\
\text { median (range) }\end{array}$ & $\begin{array}{c}\text { Controls } \\
(\mathbf{n = 2 0 )}\end{array}$ & $\mathbf{p}$ \\
median (range) & \\
\hline Inflammation intensity & $2.0(0-4)$ & $1.0(0-4)$ & 0.964 \\
$\begin{array}{l}\text { Density of iNOS (+) } \\
\text { inflammatory cells }\end{array}$ & $0.0(0-2)$ & $0.5(0-2)$ & 0.537 \\
iNOS expression & $0.0(0-2)$ & $0.5(0-2)$ & 0.641 \\
\hline
\end{tabular}

Table 4. Correlation between tissue specimen immunohistochemical parameters in the SCD patients and controls

\begin{tabular}{llcc}
\hline & \multicolumn{1}{c}{$\begin{array}{c}\text { Density of } \\
\text { iNOS (+) } \\
\text { inflammatory cells }\end{array}$} & $\begin{array}{c}\text { iNOS } \\
\text { expression }\end{array}$ \\
\hline SCD Patients & $\begin{array}{c}\text { Inflammation } \\
\text { intensity } \\
\text { Density of iNOS (+) } \\
\text { Controls }\end{array}$ & $0.604^{*}$ & $0.609^{* * *}$ \\
& $\begin{array}{c}\text { Inflammatory cells } \\
\text { intensity }\end{array}$ & $0.979^{* * *}$ \\
& $\begin{array}{c}\text { Density of iNOS (+) } \\
\text { inflammatory cells }\end{array}$ & & $0.741^{* * *}$ \\
\hline
\end{tabular}

Significant correlations: ${ }^{*} \mathrm{p}<0.05, * * \mathrm{p}<0.01$,Significant correlations: ${ }^{*} \mathrm{p}<0.05$, $* * \mathrm{p}<0.01, * * \mathrm{p}<0.001, * * * \mathrm{p}<0.001$

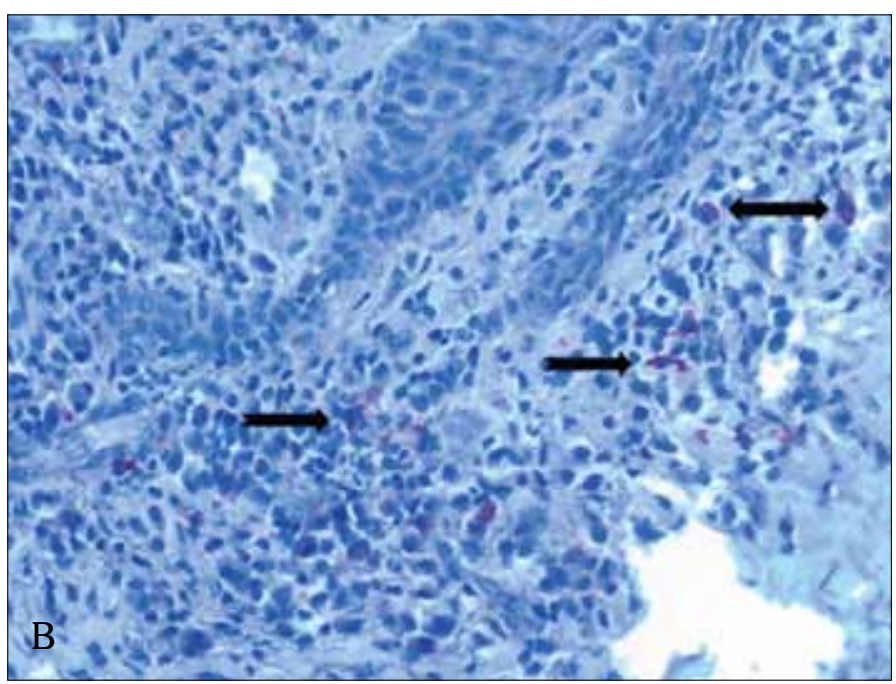

Figure 1. Immunohistochemical staining of SCD patient (A) and control tissues (B) confirmed the lack of inflammatory iNOS-expressing cells in connective tissue ( $40 \times$ magnification) 
certain temporomandibular disorders [5]. NO has been implicated in the pathogenesis of apical infection [45], periapical granulomas [46], and inflamed human dental pulp [47]. Increased iNOS expression in gingiva was shown in periodontitis [20,22,26,28,31], ligature-induced periodontitis [27], experimental periodontitis [30,46], inflamed gingiva [23], localized aggressive periodontitis [21], and recently by our group in aggressive periodontitis (unpublished data). Increased levels of $\mathrm{NO}$ in diabetic-periodontitis patients were observed in GCF [19]. Accordingly, we previously observed that inflammation and iNOS expression were higher in the gingiva of patients with both diabetes and periodontitis [48].

iNOS expression has been reported in a variety of pathogenic states characterized by oxidative stress, and inflammation and/or ischemic reperfusion [7,49]. SCD is also strongly associated with oxidative stress, increased expression of endothelial cell adhesion molecules, and blood adhesion. Increased iNOS expression and NO production have been observed in the kidneys and the liver in SCD patients [8], in mice [2,3,8,9], and in pigs [4]. During the clinically asymptomatic state, NO bioavailability is reduced in SCD patients due to scavenging of NO by cell-free hemoglobin released from hemolyzed sickle erythrocytes [50] and increased arginase activity [51]. During NO synthesis by NOS, if L-arginine levels decrease or consumption of NO increases via cell-free plasma hemoglobin and ROS, then oxidative damage occurs, $\mathrm{HbS}$ denatures, and superoxide production increases. It was shown that iNOS inhibition significantly limits tissue ischemiareperfusion injury in the liver and kidneys [10-11]; however, inhibition of iNOS attenuated ischemiareperfusion injury in the rat heart [12], but not in the rat lung [13]. Increased iNOS expression was reported in the kidneys of transgenic mice [9], but Nath et al. [14] reported the lack of iNOS upregulation in intrarenal vasculature and increased iNOS expression in the glomeruli and distal tubules of sickle mice. Previous attempts to demonstrate increased iNOS expression in SCD-affected tissues have yielded inconclusive results [52-55].

$\mathrm{NO}$ reacts with oxygen, forming nitrite $\left(\mathrm{NO}_{2}{ }^{-}\right)$ and nitrate $\left(\mathrm{NO}_{3}{ }^{-}\right)$. These oxidative metabolites of NO-referred to as $\mathrm{NO}_{\mathrm{x}}$-are often used as surrogate markers of NO production because of their instability in oxygenated environments. A deficient plasma concentration in microcirculation promotes prolonged vascular transit time. In a clinical study plasma $\mathrm{NO}_{\mathrm{x}}$ concentrations in steady-state $\mathrm{SCD}$ patients were significantly higher than in controls and there was no difference compared to the onset of painful crises [16]. Lopez et al. [56] studied adult SCD patients with vaso-occlusive crises and reported that both plasma arginine and $\mathrm{NO}_{\mathrm{x}}$ levels were significantly lower in the SCD patients than in the controls. $\mathrm{NO}_{\mathrm{x}}$ levels in children that presented during vaso-occlusive crisis were similar to baseline levels [57], in contrast to Lopez et al.'s [58] finding of low $\mathrm{NO}_{\mathrm{x}}$ levels in adults during vaso-occlusive crisis. Most studies on NOx evaluated the effects of different treatment modalities in SCD patients.

Although oral problems have been described in SCD patients, they are not as common as other medical problems. Oral problems, including unilateral infarct of the mandible [59,60], pulpal necrosis [59,61], osteonecrosis [62], facial swelling [63], diastema and hypodontia [64], gingival enlargement [63], palatal pallor [65], increased risk for caries [66], osteomyelitis of the mandible [67], unilateral anesthesia [60,62], midfacial overgrowth [65], and orofacial pain [65,67,68], have been reported [69]. As iNOS activity and expression are strongly correlated with immune and inflammatory systems, to eliminate the likelihood of conflicting results in the present study only participants that were free of clinically detectable infection and inflammation were included; the participants had no ongoing dental, periodontal, or orofacial disorders.

There are conflicting findings regarding NO levels and iNOS expression in different tissues and organs in SCD patients. This may be because NO bioavailability is controlled by several mechanisms, such as NO scavenging by plasma hemoglobin and superoxide, arginine concentration and availability by plasma arginase, NO inactivation via ROS derived from xanthine oxidase, NADPH oxidase, hemoglobin $\mathrm{S}$ and auto-oxidation, iNOS mRNA stability, post translational modification, presence of endogenous inhibitors of NOS activity, and local concentrations of arginase-inhibiting compounds [49,70]. Thusly, NO bioavailability and iNOS expression, and their roles seem to vary by organ and sometimes vary in different regions of the same organ.

In conclusion, the present findings indicate that NO levels and iNOS expression in the gingiva and GCF in SCD patients did not differ from those in 
healthy controls. Further studies are needed to clarify the role of iNOS in different tissues in SCD patients.

\section{Acknowledgments}

This study was supported by the Başkent University Research Foundation (D-KA07/01). All procedures were performed at Başkent University Laboratories (external quality control-EQAS-BIO_ RAD Lab Code Number3584-USA). The authors thank Bahar Tasdelen, MD from Mersin University, Faculty of Medicine, Department of Biostatistics, Mersin, Turkey for helping with the statistical analyses and Ms. Mine Yıldırım for editing the English language manuscript.

\section{Conflict of interest statement}

The authors of this paper have no conflicts of interest, including specific financial interests, relationships, and/or affiliations relevant to the subject matter or materials included.

\section{References}

1. Canalli AA, Franco-Penteado CF, Saad ST, Conran N, Costa FF. Increased adhesive properties of neutrophils in sickle cell disease may be reversed by pharmacological nitric oxide donation. Haematologica 2008;93:605-9. [CrossRef]

2. Diwan BA, Gladwin MT, Noguchi CT, Ward JM, Fitzhugh AL, Buzard GS. Renal pathology in hemizygous sickle cell mice. Toxicol Pathol 2002;30:254-62. [CrossRef]

3. Yu L, Gengaro PE, Niederberger M, Burke TJ, Schrier RW. Nitric oxide: a mediator in rat tubular hypoxia/ reoxygenation injury. Proc Natl Acad Sci U S A 1994;91:1691-5. [CrossRef]

4. Isobe M, Katsuramaki T, Hirata K, Kimura H, Nagayama $\mathrm{M}$, Matsuno T. Beneficial effects of inducible nitric oxide synthase inhibitor on reperfusion injury in the pig liver. Transplantation 1999;68:803-13. [CrossRef]

5. Ugar-Cankal D, Ozmeric N. A multifaceted molecule, nitric oxide in oral and periodontal diseases. Clin Chim Acta 2006;336:90-100.

6. Brown GC. Nitric oxide inhibition of cytochrome oxidase and mitochondrial respiration: implications for inflammatory, neurodegenerative and ischaemic pathologies. Mol Cell Biochem 1997;174:189-92.

7. Wood KC, Granger DN. Sickle cell disease: role of reactive oxygen and nitrogen metabolites. Clin Exp Pharmacol Physiol 2007;34:926-32. [CrossRef]

8. Aslan M, Ryan TM, Townes TM, Coward L, Kirk MC, Barnes S, Alexander CB, Rosenfeld SS, Freeman BA. Nitric oxide-dependent generation of reactive species in sickle cell disease. Actin tyrosine induces defective cytoskeletal polymerization. J Biol Chem 2003;278:4194-204.
9. Bank N, Aynedjian HS, Qiu JH, Osei SY, Ahima RS, Fabry ME, Nagel RL. Renal nitric oxide synthases in transgenic sickle cell mice. Kidney Int 1996;50:184-90. [CrossRef]

10. Lee VG, Johnson ML, Baust J, Laubach VE, Watkins SC, Billiar TR. The roles of iNOS in liver ischemia-reperfusion injury. Shock 2001;16:355-60. [CrossRef]

11. Ling $\mathrm{H}$, Gengaro PE, Edelstein CL, Martin PY, Wangsiripaisan A, Nemenoff R, et al. Effect of hypoxia on proximal tubules isolated from nitric oxide synthase knockout mice. Kidney Int 1998;53:1642-6. [CrossRef]

12. Liu P, Hock CE, Nagele R, Wong PY. Formation of nitric oxide, superoxide, and peroxynitrite in myocardial ischemia-reperfusion injury in rats. Am J Physiol 1997;272:H2327-36.

13. Moore TM, Khimenko PL, Wilson PS, Taylor AE. Role of nitric oxide in lung ischemia and reperfusion injury. Am J Physiol 1996;271:H1970-7.

14. Nath KA, Shah V, Haggard JJ, Croatt AJ, Smith LA, Hebbel RP, et al. Mechanisms of vascular instability in a transgenic mouse model of sickle cell disease. Am J Physiol Regul Integr Comp Physiol 2000;279:R1949-55.

15. Nahavandi M, Wyche MQ, Perlin E, Tavakkoli F, Castro O. Nitric Oxide Metabolites in Sickle Cell Anemia Patients after Oral Administration of Hydroxyurea; Hemoglobinopathy. Hematology 2000;5:335-9.

16. Rees DC, Cervi P, Grimwade D, O'Driscoll A, Hamilton M, Parker NE, et al. The metabolites of nitric oxide in sicklecell disease. Br J Haematol 1995;91:834-7. [CrossRef]

17. Nahavandi M, Tavakkoli F, Wyche MQ, Perlin E, Winter WP, Castro O. Nitric oxide and cyclic GMP levels in sickle cell patients receiving hydroxyurea. $\mathrm{Br} \mathrm{J}$ Haematol 2002;119:855-7. [CrossRef]

18. Nahavandi M, Tavakkoli F, Millis RM, Wyche MQ, Habib MJ, Tavakoli N. Effects of hydroxyurea and L-arginine on the production of nitric oxide metabolites in cultures of normal and sickle erythrocytes. Hematology 2006;11:291-4. [CrossRef]

19. Skaleric U, Gaspirc B, McCartney-Francis N, Masera A, Wahl SM. Proinflammatory and antimicrobial nitric oxide in gingival fluid of diabetic patients with periodontal disease. Infect Immun 2006;74:7010-3. [CrossRef]

20. Lappin DF, Kjeldsen M, Sander L, Kinane DF. Inducible nitric oxide synthase expression in periodontitis. J Periodontal Res 2000;35:369-73. [CrossRef]

21. Gaspirc B, Masera A, Skaleric U. Immunolocalization of inducible nitric oxide synthase in localized juvenile periodontitis patients. Connect Tissue Res 2002;43:4138. [CrossRef]

22. Batista AC, Silva TA, Chun JH, Lara VS. Nitric oxide synthesis and severity of human periodontal disease. Oral Dis 2002;8:254-60. [CrossRef]

23. Hirose M, Ishihara K, Saito A, Nakagawa T, Yamada S, Okuda K. Expression of cytokines and inducible nitric oxide synthase in inflamed gingival tissue. J Periodontol 2001;72:590-7. [CrossRef]

24. Lohinai Z, Stachlewitz R, Virag L, Szekely AD, Hasko G, Szabo C. Evidence for reactive nitrogen species formation in the gingivomucosal tissue. J Dent Res 2001;80:470-5. [CrossRef] 
25. Kendall HK, Haase HR, Li H, Xiao Y, Bartold PM. Nitric oxide synthase type-II is synthesized by human gingival tissue and cultured human gingival fibroblasts. J Periodontal Res 2000;35:194-200. [CrossRef]

26. Matejka M, Partyka L, Ulm C, Solar P, Sinzinger H. Nitric oxide synthesis is increased in periodontal disease. $\mathrm{J}$ Periodontal Res 1998;33:517-8. [CrossRef]

27. Lohinai Z, Benedek P, Fehér E, Györfi A, Rosivall L, Fazekas A, Salzman AL, Szabó C. Protective effects of mercaptoethylguanidine, a selective inhibitor of inducible nitric oxide synthase, in ligature-induced periodontitis in the rat. Br J Pharmacol 1998;123:353-60. [CrossRef]

28. Daghigh F, Borghaei RC, Thornton RD, Bee JH. Human gingival fibroblasts produce nitric oxide in response to proinflammatory cytokines. J Periodontol 2002;73:392-400. [CrossRef]

29. Paquette DW, Williams RC. Modulation of host inflammatory mediators as a treatment strategy for periodontal diseases. Periodontol 2000 2000;24:239-52. [CrossRef]

30. Popkov VL, Fil'chukova IA, Lapina NV, GalenkoYaroshevskii VP, Dukhanin AS. Activity of nitric oxide synthase and concentration of nitric oxide end metabolites in the gingiva under experimental pathological conditions. Bull Exp Biol Med 2005;140:391-3. [CrossRef]

31. Gullu C, Ozmeric N, Tokman B, Elgun S, Balos K. Effectiveness of scaling and root planing versus modified Widman flap on nitric oxide synthase and arginase activity in patients with chronic periodontitis. J Periodontal Res 2005;40:168-75. [CrossRef]

32. Alayan J, Ivanovski S, Gemmell E, Ford P, Hamlet S, Farah CS. Deficiency of iNOS contributes to Porphyromonas gingivalis-induced tissue damage. Oral Microbiol Immunol 2006;21:360-5. [CrossRef]

33. Gyurko R, Boustany G, Huang PL, Kantarci A, Van Dyke TE, Genco CA, Gibson FC 3rd. Mice lacking inducible nitric oxide synthase demonstrate impaired killing of orphyromonas gingivalis. Infect Immun 2003;71:4917-24. [CrossRef]

34. Gyurko R, Shoji H, Battaglino RA, Boustany G, Gibson FC 3rd, Genco CA, Stashenko P, Van Dyke TE. Inducible nitric oxide synthase mediates bone development and P. gingivalis-induced alveolar bone loss. Bone 2005;36:472-9. [CrossRef]

35. Garlet GP, Cardoso CR, Campanelli AP, Garlet TP, AvilaCampos MJ, Cunha FQ, Silva JS. The essential role of IFN-gamma in the control of lethal Aggregatibacter actinomycetemcomitans infection in mice. Microbes Infect 2008;10:489-96. [CrossRef]

36. Zamora R, Vodovotz Y, Billiar TR. Inducible nitric oxide synthase and inflammatory diseases. Mol Med 2000;6:347-73.

37. Hickey MJ. Role of inducible nitric oxide synthase in the regulation of leucocyte recruitment. Clin Sci (Lond) 2001;100:1-12. [CrossRef]

38. Ozmeric N. Advances in periodontal disease markers. Clin Chim Acta 2004;343:1-16. [CrossRef]

39. Ricart-Jane D, Llobera M, Lopez-Tejero MD. Anticoagulants and other preanalytical factors inter- fere in plasma nitrate/nitrite quantification by the Griess method. Nitric Oxide 2002;6:178-85.

40. Mirbod SM, Ahing SI, Pruthi VK. Immunohistochemical study of vestibular gingival blood vessel density and internal circumference in smokers and non-smokers. J Periodontol 2001;72:1318-23. [CrossRef]

41. Brennan PA, Palacios-Callender M, Sinclair D, Spedding AV, Zaki GA. Does expression of inducible nitric oxide synthase correlate with severity of oral epithelial dysplasia? J Craniomaxillofac Surg 2000;28:44-8. [CrossRef]

42. Erkurt MA, Aydogdu I, Bayraktar N, Kuku I, Kaya E. The levels of nitric oxide in megaloblastic anemia. Turk J Hematol 2009;26:197-200.

43. Bayraktar N, Erkurt MA, Aydogdu I, Basaran Y. The levels of nitric oxide in beta-thalassemia minor. Turk $\mathrm{J}$ Hematol 2008; 25:187-9.

44. Ohashi M, Iwase M, Nagumo M. Elevated production of salivary nitric oxide in oral mucosal diseases. J Oral Pathol Med 1999;28:355-9. [CrossRef]

45. Shimauchi H, Takayama S, Narikawa-Kiji M, Shimabukuro Y, Okada H. Production of interleukin-8 and nitric oxide in human periapical lesions. J Endod 2001;27:749-52. [CrossRef]

46. Hama S, Takeichi O, Saito I, Ito K. Involvement of inducible nitric oxide synthase and receptor for advanced glycation end products in periapical granulomas. J Endod 2007;33:137-41. [CrossRef]

47. Di Nardo Di Maio F, Lohinai Z, D'Arcangelo C, De Fazio PE, Speranza L, De Lutiis MA, Patruno A, Grilli A, Felaco M. Nitric oxide synthase in healthy and inflamed human dental pulp. J Dent Res 2004;83:312-6. [CrossRef]

48. Pan Z, Guzeldemir E, Toygar HU, Bal N, Bulut S. Nitric Oxide Synthase in Gingival Tissues of Patients With Chronic Periodontitis and With and Without Diabetes. Journal of Periodontology 2010;81:109-20. [CrossRef]

49. Wood KC, Hsu LL, Gladwin MT. Sickle cell disease vasculopathy: a state of nitric oxide resistance. Free Radic Biol Med 2008;44:1506-28. [CrossRef]

50. Reiter CD, Wang X, Tanus-Santos JE, Hogg N, Cannon RO, 3rd, Schechter AN, et al. Cell-free hemoglobin limits nitric oxide bioavailability in sickle-cell disease. Nat Med 2002;8:1383-9. [CrossRef]

51. Schnog JJ, Jager EH, van der Dijs FP, Duits AJ, Moshage $\mathrm{H}$, Muskiet FD, Muskiet FA. Evidence for a metabolic shift of arginine metabolism in sickle cell disease. Ann Hematol 2004;83:371-5.

52. Wood KC, Hebbel RP, Lefer DJ, Granger DN. Critical role of endothelial cell-derived nitric oxide synthase in sickle cell disease-induced microvascular dysfunction. Free Radic Biol Med 2006;40:1443-53.

53. Osei SY, Ahima RS, Fabry ME, Nagel RL, Bank N. Immunohistochemical localization of hepatic nitric oxide synthase in normal and transgenic sickle cell mice: the effect of hypoxia. Blood 1996;88:3583-8.

54. Bank N, Kiroycheva M, Singhal PC, Anthony GM, Southan GJ, Szabo C. Inhibition of nitric oxide synthase ameliorates cellular injury in sickle cell mouse kidneys. Kidney Int 2000;58:82-9. 
55. Kaul DK, Liu XD, Fabry ME, Nagel RL. Impaired nitric oxide-mediated vasodilation in transgenic sickle mouse. Am J Physiol Heart Circ Physiol 2000;278: H1799-806.

56. Lopez BL, Kreshak AA, Morris CR, Davis-Moon L, Ballas SK, Ma XL. L-arginine levels are diminished in adult acute vaso-occlusive sickle cell crisis in the emergency department. Br J Haematol 2003;120:532-4.

57. Morris CR, Kuypers FA, Larkin S, Vichinsky EP, Styles LA. Patterns of arginine and nitric oxide in patients with sickle cell disease with vaso-occlusive crisis and acute chest syndrome. J Pediatr Hematol Oncol 2000;22:515-20.

58. Lopez BL, Barnett J, Ballas SK, Christopher TA, DavisMoon L, Ma X. Nitric oxide metabolite levels in acute vaso-occlusive sickle-cell crisis. Acad Emerg Med 1996;3:1098-103.

59. Kavadia-Tsatala S, Kolokytha O, Kaklamanos EG, Antoniades K, Chasapopoulou E. Mandibular lesions of vasoocclusive origin in sickle cell hemoglobinopathy. Odontology 2004;92:68-72.

60. Bishop K, Briggs P, Kelleher M. Sickle cell disease: a diagnostic dilemma. Int Endod J 1995;28:297-302.

61. Demirbas Kaya A, Aktener BO, Unsal C. Pulpal necrosis with sickle cell anaemia. Int Endod J 2004;37:602-6.

62. Kelleher M, Bishop K, Briggs P. Oral complications associated with sickle cell anemia: a review and case report. Oral Surg Oral Med Oral Pathol Oral Radiol Endod 1996;82:225-8.

63. Scipio JE, Al-Bayaty HF, Murti PR, Matthews R. Facial swelling and gingival enlargement in a patient with sickle cell disease. Oral Dis 2001;7:306-9.

64. Oredugba FA. Hypodontia in an adolescent with the HbSC genotype: a case report. Int $\mathrm{J}$ Paediatr Dent 2005;15:455-8.

65. Rada RE, Bronny AT, Hasiakos PS. Sickle cell crisis precipitated by periodontal infection: report of two cases. J Am Dent Assoc 1987;114:799-801.

66. Laurence B, George D, Woods D, Shosanya A, Katz RV, Lanzkron S, Diener-West M, Powe N. The association between sickle cell disease and dental caries in African Americans. Spec Care Dentist 2006;26:95-100.

67. Shroyer JV, 3rd, Lew D, Abreo F, Unhold GP. Osteomyelitis of the mandible as a result of sickle cell disease. Report and literature review. Oral Surg Oral Med Oral Pathol 1991;72:25-8.

68. O'Rourke CA, Hawley GM. Sickle cell disorder and orofacial pain in Jamaican patients. Br Dent J 1998;185:90-2.

69. Carr MM. Dental management of patients with sickle cell anemia. J Can Dent Assoc 1993;59:180-2, 185.

70. Suschek CV, Schnorr O, Kolb-Bachofen V. The role of iNOS in chronic inflammatory processes in vivo: is it damage-promoting, protective, or active at all? Curr Mol Med 2004;4:763-75. 